\title{
New Solar Water Heating System: Safety, Design and Implementation Issues
}

\author{
Victor D. N. Santos ${ }^{1,2}$, Manuel Cerveira ${ }^{1}$ \\ ${ }^{1}$ Polytechnic Institute of Coimbra - \\ Coimbra Institute of Engineering (IPC-ISEC) \\ Rua Pedro Nunes - Quinta da Nora \\ 3030-199 Coimbra, Portugal
}

\author{
Fernando Moita ${ }^{1}$ \\ ${ }^{2}$ Institute for Systems and Computers Engineering at \\ Coimbra - INESC Coimbra (R\&D Unit) \\ Rua Sílvio Lima, Pólo II \\ 3030-290 Coimbra, Portugal
}

\begin{abstract}
This paper presents a new electronic controller, devoted to solar water heating systems, that implements safety functions to prevent $L$. pneumophila bacteria outbreaks. The controller uses data retrieved from strategically located probes in order to implement the proposed safety actions. The electronic solution was integrated and validated on a solar system prototype bench that uses real equipment such as collectors, a water storage tank and expansion vessels. Moreover, two particular solar water heating installations were designed devoted to a house family and a nursing home both located on the Mealhada area. The methodology and reported technical solutions in this research could be a practical guide to promote mass market usage of the solar water heating systems in Portugal.
\end{abstract}

Keywords - Solar thermal, water heating systems, safety issues, Legionella.

\section{INTRODUCTION}

In the last two decades there was a significant growth in the number of solar water heating system installed in Portugal. The country has excellent conditions to make use of solar energy. In average Portugal has 2600 hours of sunshine per year [1,2], with significant values of irradiation, being therefore one of the European countries with higher potential to use solar systems. The economic incentives for the purchase of solar thermal panels, given by some Governments, before the economic crisis, have also contributed to promote the use of renewable energies reducing the fossil fuels consumption and the country energy external dependence.

Nowadays, solar thermal energy is mainly used to heat water for residential consumption, swimming pools, hotels, etc. In addition, it can be used to generate hot air for house heating and in solar air-conditioning through the use of absorption chillers. It can be used also in agriculture (heating greenhouses) and in some industrial processes $[3,4]$.

Regarding solar water heating systems it is recognized that they need a careful maintenance to ensure their safe operation as regards the installation components and users health. In recent years it was observed a growing number of Legionella pneumophila outbreaks in solar water heating system as well as in refrigeration towers. Exposure to these bacteria can cause a respiratory infection, known as Legionnaires' disease that is transmitted by inhalation of contaminated water vapor droplets that convey the bacteria into the lungs.

In the last three years, in addition to the most serious case recorded in November 2014 in the municipality of Vila Franca de Xira, responsible for 12 deaths and 375 Legionella patients, and in recent case occurred at São Francisco Xavier Hospital, in Lisbon in November 2017 the bacteria was detected without causing infections in hospitals (Régua, Bragança) at the health center of Vila Real de Santo António, municipal swimming pools (Arouca, Castro Marim), at a hotel in Oporto, at a campsite in Peniche and in a factory in Sines [5].

These events prompted the development of novel solutions to be included in new and existing solar systems devoted to water heating, namely those that include the closed hot water recirculation. In the literature the prevention of L. pneumophila and other micro-organisms, in these systems, is completed either by thermal disinfection or by chemical disinfection or by a combination of both.

Thermal desinfectation is accomplished by heating the water stored in the accumulator at temperatures higher that $70{ }^{\circ} \mathrm{C}$ [6]. In addition, the water temperature should be always higher than $60^{\circ} \mathrm{C}$ in the consumption points and higher than $55^{\circ} \mathrm{C}$ in the return path, for systems with recirculation. The thermal disinfection presents some disadvantages namely an increase on the energy consumed by the conventional systems during the water overheating process and a risk of scalding.

This paper presents: 1) A novel solar controller devoted to thermal solar systems that prevents the L. pneumophila outbreaks appearance and protects the installation components (collectors, pipes and storage tank) from extreme temperature events; 2) the design of a solar system devoted to two different scenarios: a detached house and a nursing home using the SolTerm ${ }^{\mathrm{TM}}$ tool, in order to accomplish high energy management standards. Moreover, a prototype was built to illustrate the effectiveness of the proposed method on a solar water heating system.

This paper is organized as follows. In Section 2, the solar system design is presented accordingly with the national 
regulation in the scope of thermal behavior characteristics in buildings. Section 3 presents the solar system experimental setup developed in the scope of this work. In Section 4, an improved microcontroller solution is presented to implement the proposed safety and energy management functions. Finally, Section 5 presents the main conclusions and future work.

\section{SOlAR SYSTEM DESIGN}

The new regulation of thermal behavior characteristics in buildings that became effective with the law DL 80/2006 publication [7] that rules among others, solar thermal energy systems design devoted to Domestic Hot Water (DHW). This legislation makes mandatory the existence of a solar thermal energy system, both for new houses on construction, and for those that suffer significant changes. The existence of specific legislation in the district where the solar thermal system installation is located should also be respected.

In order to ensure compliance with the law, the Instituto Nacional de Engenharia, Tecnologia e Inovação (INETI) has developed a software tool named SolTerm ${ }^{\mathrm{TM}}$. This software performs the design of solar systems (thermal and electric), allowing to the energy agency (ADENE) a greater efficiency in the control and monitoring of the projects in this area.

In [8] the author defines a procedure to be carried out in a solar thermal systems design, suited to a block of flats building. That procedure was extrapolated to our single family house scenario and comprises the following steps:

- Selection of the type of solution to be implemented, which depends on the house configuration, technical areas availability and the desired comfort level;

- Quantification of the hot water consumption volume according to current regulation. For residential building, this value is often associated with the number of users;

- Selection of the water tank (volume and model), to be installed in a technical area inside the house, based on: the hot water consumption needs, space limitations and house structure;

- Definition of support equipment to be applied.

Location is a key factor in the system design taking into account that the collectors' performance depends on the weather conditions at that particular region.

Moreover, the local where the collectors will be installed must have some specific characteristics, namely: available space for the collector's installation, suitable orientation and inclination, and inexistence of shadows on the collectors produced by surrounding obstacles.

SolTerm ${ }^{\mathrm{TM}}$ software provides solar radiation data specific to any location in Portugal. The horizontal daily solar radiation and ambient temperature values with respect to a location in the Mealhada municipality are depicted in Fig. 1.

The maximum daily horizontal solar radiation was equal to $6.7 \mathrm{kWh} / \mathrm{m}^{2}$ and occurred in July. To this value contribute both the diffused component and the direct component whose values equals $2.5 \mathrm{kWh} / \mathrm{m}^{2}$ and $4.2 \mathrm{kWh} / \mathrm{m}^{2}$ respectively. The lowest daily horizontal solar radiation value occurred in December with similar contributions from the direct and diffuse components, and was equal to $1.7 \mathrm{kWh} / \mathrm{m}^{2}$.

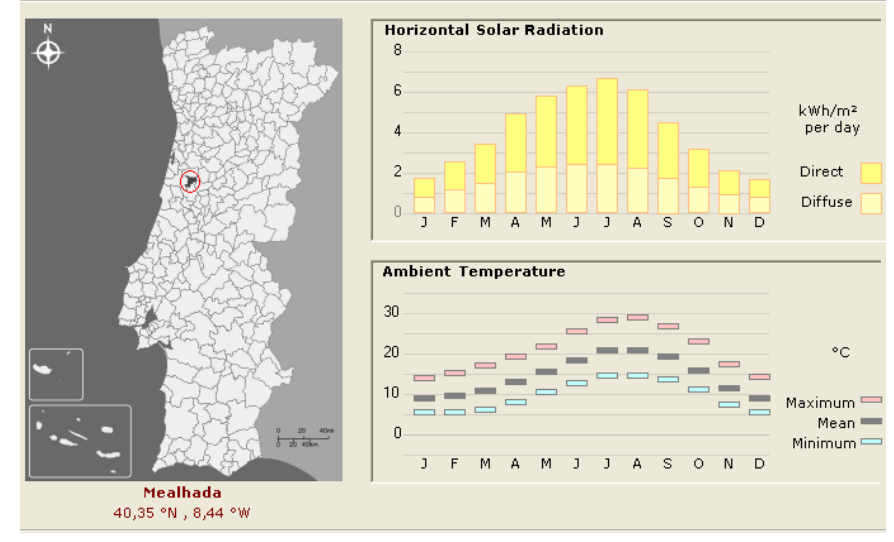

Fig. 1. Solar system performance: monthly analysis.

The minimum value of ambient temperature is crucial to define the water and glycol mixture percentage as solar fluid, for heat transfer. For a location in Mealhada this minimum temperature value was not available, however, in Coimbra at a approximately $10 \mathrm{~km}$ apart from Mealhada with similar weather conditions it was found that in the period 1971-2000, the highest and lowest temperatures recorded were respectively $41.6^{\circ} \mathrm{C}$ and $-4.9^{\circ} \mathrm{C}$ [9]. However, there are records of $-7.8^{\circ} \mathrm{C}$ in 1941 and $42.5^{\circ} \mathrm{C}$ in 1943 .

Based on the aforementioned national regulations "Regulamento das Características de Comportamento Térmico dos Edifícios" (RCCTE) information (Annex VI), it was considered that water supply network provides cold water with an average annual temperature of $15^{\circ} \mathrm{C}$, being thereafter heated to $60{ }^{\circ} \mathrm{C}$ for domestic consumption.

Solar thermal systems installations, besides the compliance with regulation, should include the most appropriated procedures to reach the best results in terms of useful lifetime of the facilities and installation cost-effectiveness. To ensure the best conditions of operation and use for all the solar system components, the procedures described by the equipment manufacturers should be applied. Regarding the orientation of the solar collectors, the ideal heading is the geographic south, however for aesthetic reasons or others, deviations up to $20^{\circ}$ to east or west are accepted.

With regard to the pitch, the optimum slope of the collectors for maximum advantage during the whole year is between $35^{\circ}$ and $55^{\circ}$, the values must be adjusted depending on the location and the conditions of each particular system. In Portugal, in order to maximize the advantage throughout the year, collectors should be installed in the north zone, with a slope close to $37^{\circ}$. For the central and south areas of the country the slope values are respectively equal to $34^{\circ}$ and $32^{\circ}$.

Pitch deviations of $\pm 15^{\circ}$ are accepted when the maximum advantage occurs at specific months which usually correspond to the highest concentration of solar water heating systems' users. 


\section{A. Scenario I: Detached Family House Installation}

In the house family installation scenario it was assumed a house with 4 individuals, with a DHW consumption equally divided by the morning and evening periods. The selected profile assumes the consumption of 40 liters per day per user, resulting in 160 liters distributed as follows: 80 liters at the morning period between 7 to $8 \mathrm{a} . \mathrm{m}$. and 80 liters at the afternoon period from 6 to 7 p.m.

From the results obtained by simulation in SolTerm ${ }^{\mathrm{TM}}$ software, and shown in Fig. 2, a house with four users will need $3056 \mathrm{kWh}$ of energy per year, in conventional preparation of DHW based on the consumption profile earlier presented. This value matches the results obtained with the RCCTE formula.

\begin{tabular}{|c|c|c|c|c|c|c|}
\hline & Horiz. Rad. & Inclin. Rad. & Waste & Provided & Load & Support \\
\hline & $\mathrm{kTh} / \mathbb{\pi}^{2}$ & $\mathrm{kWh} / \mathbb{m}^{2}$ & $\mathrm{k}$ thin & $\mathrm{kTh}$ & kth & kWh \\
\hline January & 55 & 93 & , & 124 & 260 & 135 \\
\hline February & 72 & 106 & , & 132 & 234 & 103 \\
\hline March & 107 & 131 & , & 156 & 260 & 103 \\
\hline April & 148 & 157 & , & 182 & 251 & 69 \\
\hline May & 181 & 175 & , & 199 & 260 & 61 \\
\hline June & 190 & 174 & , & 196 & 251 & 56 \\
\hline July & 208 & 196 & , & 223 & 260 & 37 \\
\hline August & 189 & 195 & , & 232 & 260 & 28 \\
\hline September & 134 & 157 & ; & 197 & 251 & 54 \\
\hline October & 99 & 140 & ; & 181 & 260 & 78 \\
\hline November & 64 & 106 & , & 138 & 251 & 114 \\
\hline December & 52 & 91 & , & 124 & 260 & 135 \\
\hline Annual & 1499 & 1722 & , & 2084 & 3056 & 972 \\
\hline & bal system & Jal efficien & $2 \%$ & Yield: & $\begin{array}{l}\text { lar fract } \\
\mathrm{kwh} /[\end{array}$ & $\begin{array}{l}n: 68,2 \% \\
2 \text { collector }\end{array}$ \\
\hline
\end{tabular}

Fig. 2. Solar system performance: Scenario I.

In order to reduce the energy used to heat water from conventional sources (electricity and gas) a new system comprising two solar thermal collectors Zantia ZHS 200 and an accumulator with 200 liters of capacity has been proposed. This system will produce $2084 \mathrm{kWh}$ per year, resulting in an average annual solar fraction of $68.2 \%$ and a yield value of $543 \mathrm{kWh} /\left(\mathrm{m}^{2}\right.$ collector $)$.

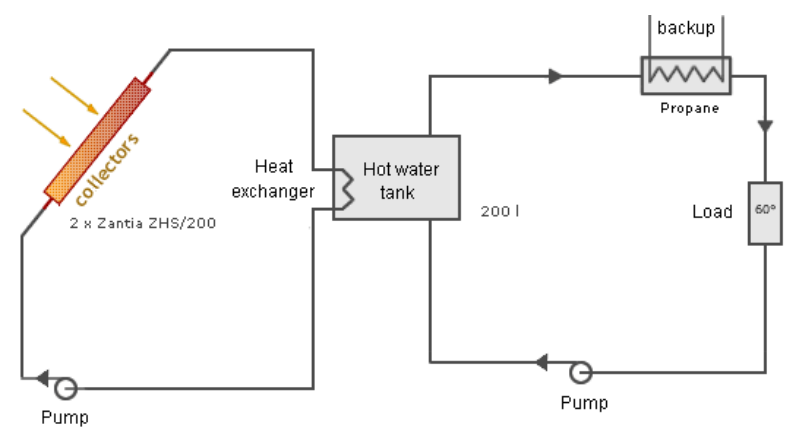

Fig. 3. Simulated solar system for a family house.

As aforementioned, given the small number of users and the considered DHW consumption profile, based on RCCTE (Annex VI), one Zantia model S20-200 accumulator with a capacity of 200 liters was selected, as illustrated in Fig. 3. The considered hot water deposit is made of stainless steel, has cylindrical shape and will be installed inside the house in a vertical position. Moreover, the heat exchanger (coil) placed in the deposit presents an efficiency value equal to $55 \%$. The information related with the storage deposit including its dimensions should be set in a specific SolTerm ${ }^{\mathrm{TM}}$ editor.

Table I summarizes the main characteristics of the solar thermal system that has been analyzed and designed for a local standard four user's family house.

TABLE I. SOlAR SYSTEM CHARACTERISTICS [10].

\begin{tabular}{|l|l|}
\hline District/province & Mealhada \\
\hline Obstructions & none \\
\hline Consumption profile & RCCTE (4 users) \\
\hline Thermal system & Forced circulation \\
\hline Collectors area & $\sim 4 \mathrm{~m}^{2}$ \\
\hline Storage tank capacity & 2001 \\
\hline Piping & $20 \mathrm{~m}$ \\
\hline Support system (natural gas) & $88 \%$ \\
\hline Heat exchanger (coil): & $55 \%$ \\
\hline Consumption temperature & $60{ }^{\circ} \mathrm{C}$ \\
\hline Water temperature (network) & $15^{\circ} \mathrm{C}$ \\
\hline
\end{tabular}

\section{B. Scenario II: Nursing Home Installation}

As mentioned previously, the promotion of the use of renewable energies, through incentives for the purchase of solar thermal panels was used for residential customers and social services institutions (nursing home; kindergartens and day care centers) to reduce the energy bill.

So, as in many other institutions in Portugal, one nursing home institution located in the municipality of Mealhada, promoted the implementation of a solar energy installation for DHW heating to be used by their users and service personnel. The system was designed taken into account the number of users of the nursing home, around 120 plus the staff personnel. The DHW consumption profile, presented in Table II, assumes a different number of users: during the day and night periods and during the weekdays and weekends. The nursing home population statistics were obtained directly from its' directors.

TABLE II. NURSING Home DHW CONSUMPTION PROfILE.

\begin{tabular}{|c|c|c|c|c|c|c|}
\hline \multirow{2}{*}{ Period } & \multicolumn{3}{|c|}{ Weekdays } & \multicolumn{3}{c|}{ Weekends } \\
\cline { 2 - 7 } & $\begin{array}{c}\text { Number } \\
\text { of users }\end{array}$ & $\begin{array}{c}\text { DHW } \\
\text { by user }\end{array}$ & $\begin{array}{c}\text { Total } \\
\text { DHW }\end{array}$ & $\begin{array}{c}\text { Number } \\
\text { of users }\end{array}$ & $\begin{array}{c}\text { DHW } \\
\text { per user }\end{array}$ & $\begin{array}{c}\text { Total } \\
\text { DHW }\end{array}$ \\
\hline $07-09$ & 50 & 25 & 1250 & 40 & 25 & 1000 \\
\hline $09-12$ & 120 & 2 & 240 & 80 & 2 & 160 \\
\hline $12-14$ & 120 & 5 & 600 & 80 & 5 & 400 \\
\hline $14-18$ & 120 & 3 & 360 & 80 & 3 & 240 \\
\hline $18-21$ & 120 & 5 & 600 & 80 & 5 & 400 \\
\hline $21-07$ & 50 & 3 & 150 & 40 & 3 & 120 \\
\hline Average DHW consumption & 3200 & & & 2320 \\
\hline
\end{tabular}

The implemented solution aims to reduce the energy costs associated with the DHW heating from conventional sources. It uses 32 Zantia ZHS 200 solar collectors, similar to the ones used in detached house, and a hot water storage tank, with 3000 liters of capacity, described in detail in table III.

The planned solar thermal system was simulated using the SolTerm ${ }^{\mathrm{TM}}$ software tool. The obtained results, presented in Fig. 4, showed that the solution with 32 solar collectors is suitable for the maximum DHW consumption of the nursing 
home, which occurs on weekdays and is compliant with the RCCTE and RSECE legislation.

TABLE III. ACCUMULATOR TANK CHARACTERISTICS.

\begin{tabular}{|l|l|}
\hline Capacity (1) & 30001 (liters) \\
\hline Inner diameter (cm): & 180,0 \\
\hline Insulation thickness (cm): & 15,0 \\
\hline Height (m): & 2,95 \\
\hline Thermal losses (W/K): & 16,9 \\
\hline Efficiency (\%): & $55 \%$ \\
\hline Heat exchanger: & interior \\
\hline
\end{tabular}

From the obtained results it can be also observed that the energy spent monthly obtaining DHW is not constant, it varies accordingly with the number of days and weekends of each particular month.

The energy needed to heat the water form the water supply network to the desired temperature $\left(60^{\circ} \mathrm{C}\right)$, over one year, is equal to $56327 \mathrm{kWh}$. The reduced horizontal and vertical radiation values observed between November and March, lead to higher energy values obtained from conventional backup systems. For example in December the solar system produces $2310 \mathrm{kWh}$ of energy and the support system the remaining $2420 \mathrm{kWh}$.

\begin{tabular}{|c|c|c|c|c|c|c|}
\hline & Horiz. Rad. & Inclin. Rad. & Waste & Provided & Load & Support \\
\hline & $\mathrm{kTWh} / \mathbb{m}^{2}$ & $\mathrm{kTh} / \mathbb{m}^{2}$ & $\mathrm{kThh}$ & $\mathrm{kthh}$ & $\mathrm{kTh}$ & kth \\
\hline January & 55 & 93 & , & 2363 & 4822 & 2459 \\
\hline February & 72 & 106 & , & 2488 & 4320 & 1831 \\
\hline March & 107 & 131 & , & 2992 & 4776 & 1784 \\
\hline April & 148 & 157 & , & 3470 & 4609 & 1138 \\
\hline May & 181 & 175 & 1, & 3851 & 4822 & 972 \\
\hline June & 190 & 174 & , & 3721 & 4609 & 888 \\
\hline July & 208 & 196 & 2 & 4226 & 4776 & 551 \\
\hline August & 189 & 195 & 4 & 4465 & 4822 & 358 \\
\hline September & 134 & 157 & 1, & 3722 & 4563 & 840 \\
\hline October & 99 & 140 & , & 3515 & 4822 & 1307 \\
\hline November & 64 & 106 & , & 2606 & 4655 & 2049 \\
\hline December & 52 & 91 & , & 2310 & 4730 & 2420 \\
\hline Annual & 1499 & 1722 & 9, & 39730 & 56327 & 16597 \\
\hline & ste & cie & & Yield & $7 \mathrm{kwh}$ & $\begin{array}{l}: 70,5 \% \\
\text { collector }\end{array}$ \\
\hline
\end{tabular}

Fig. 4. Solar system performance: Scenario II.

Summarizing the planned system will produce $39730 \mathrm{kWh}$ per year, resulting in an average annual solar fraction of $70.5 \%$ and a yield value of $647 \mathrm{kWh} /\left(\mathrm{m}^{2}\right.$ collector $)$.

The presented solution assumes an additional hot water accumulator with 500 liters of capacity positioned in cascade with the previous one, in order to ensure hot water at the desired temperature even in those periods with reduced or inexistent solar radiation. The water stored in smallest storage tank is heated using a conventional system based on electricity, gas or biomass.

\section{SOLAR SYSTEM PROTOTYPE}

Solar water heating systems includes solar collectors, water storage tanks, pipes and expansion vessels. Forced circulation systems (Fig. 5) use electrical pumps to force the fluid flow through collectors and the storage tank. To ensure maximum heat exchange advantage, an electronic control unit manages the circulating pump operation, according to appropriated instructions.

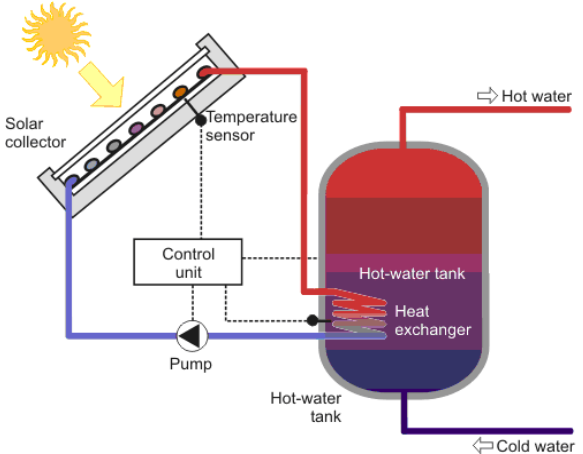

Fig. 5. Forced circulation thermal solar system. (Adapted from [10])

An experimental bench that replicates a thermal solar forced circulation system intended for a family of four was constructed using the following equipment:

- Collector plane VH4L K423 - $2.51 \mathrm{~m}^{2}$ area;

- Water Accumulator WBO 212 DUO;

- Hydraulic kit;

- Solar fluid expansion vessel;

- DHW expansion vessel;

- Joint connection for expansion vessel;

- Solar fluid;

- Solar system control unit;

- Inclined roof support metallic structure;

- Thermostatic mixing valve $3 / 4 "$.

The prototype, shown in Fig. 6, was also prepared to be used in teaching activities related with the renewable energy topics addressed in several units and courses of the Anadia high school. Later on, the mentioned prototype was used to validate the developed electronic unit with the new control algorithms.

The metallic structure that supports the experimental bench equipment replicates a house and includes the following parts:

- Lower floor reinforced construction, built in steel sheet. The floor plate is rectangular and has an approximate area of $3.65 \mathrm{~m}^{2}$. To allow mobility of the entire installation bench, for didactic purposes, a set of wheels were included bellow the structure;

- A back wall with 2570 × 2460 mm and two side's walls with $2460 \times 1470 \mathrm{~mm}$ each built on undulating transparent acrylic sheet, were attached to the metal structure consisting of pillars in steel tube welded to the floor steel plate;

- Roof support metallic structure built on steel tube, fixed by welding, supports an anodized aluminum profile base on top of which the solar collectors have been installed. 


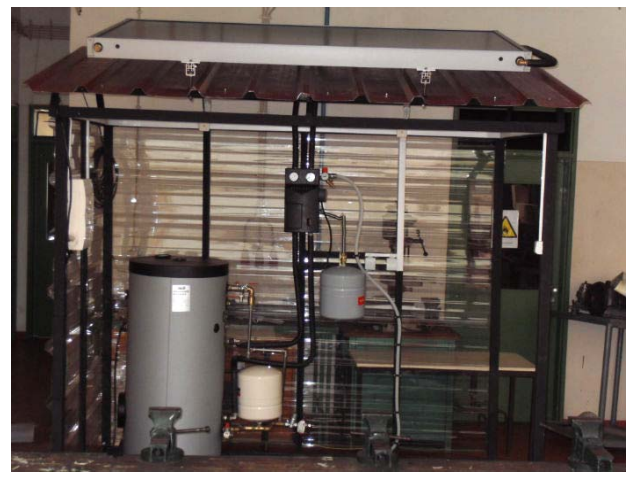

Fig. 6. Solar thermal system experimental bench.

\section{A. Legionella Bacteria Control}

Legionella pneumophila bacteria proliferation is liable to occur in solar systems with hot water storage tank and return circuit. Thus, in order to prevent the development and dissemination of legionellas, some actions must be taken [2], [6] and [11]:

- Water storage tanks should be installed in ventilated areas in order to preserve the temperature of the cold water at a temperature not exceeding $20^{\circ} \mathrm{C}$;

- According to Table II, hot water temperatures in the range 20 and $50{ }^{\circ} \mathrm{C}$ should be avoided. Thus, the water temperature in the storage tank must be always around $60^{\circ} \mathrm{C}$;

- The stored hot water temperature should be raised by the backup system electric or gas above $70^{\circ} \mathrm{C}$ at least once per week by a control unit order. Accordingly with the information presented in Table II, at that particular temperature value the L. pneumophila bacteria are instantaneously eliminated.

TABLE IV. Temperature EFFECTS ON THE Legionella SURViVAL [6].

\begin{tabular}{|c|l|}
\hline Temperature & \multicolumn{1}{|c|}{ State } \\
\hline$<20^{\circ} \mathrm{C}$ & Bacteria survive but are dormant \\
\hline $20^{\circ} \mathrm{C} \leq \mathrm{T}<35^{\circ} \mathrm{C}$ & Bacteria begin to reproduce \\
\hline $35^{\circ} \mathrm{C} \leq \mathrm{T}<48^{\circ} \mathrm{C}$ & Ideal growth range of the bacterium \\
\hline $50^{\circ} \mathrm{C}$ & $90 \%$ of bacteria die after 2 hours \\
\hline $60^{\circ} \mathrm{C}$ & $90 \%$ of bacteria die after 2 minutes \\
\hline $70^{\circ} \mathrm{C}$ & The bacteria die almost instantly \\
\hline
\end{tabular}

\section{B. Solar System Controller}

The solar system analyzed in this paper consists of a set of solar collectors, a pump to force the circulation of the heating transfer fluid (water + glycol), an electrical resistance as a backup system and five temperature probes.

The implemented electronic differential controller is suited only to force circulation solar system. Its main function is to control the flux of the fluid heated in the collectors that circulates through the interconnected pipes between the collectors and the storage tank.

The temperature data are measured by PT1000 probes, properly disposed by the solar installation, being thereafter handled by the control unit. According with the measured values, the control unit will actuate the different components, operating valves, pumps and dispensers. Furthermore, the LCD display shows the system parameters, information and reports the operation state of the equipment.

The control unit continuously analyzes the temperature difference between the hottest spot on the collectors and the coldest point of the solar thermal system, in the storage tank, activating or stopping the circulation pump.

\section{Control Unit Hardware Design}

The implemented electronic differential controller devoted to solar systems management, presented in Fig. 7, was based on the low cost 40-pin PIC16F887 microcontroller from Microchip, whose available functionalities are appropriated to the solution under analysis. The following elements were integrated into the main circuit board: Microcontroller 16F887; Real Time Clock (RTC); Display - LCD 16 x 2 and Keyboard four operation buttons.

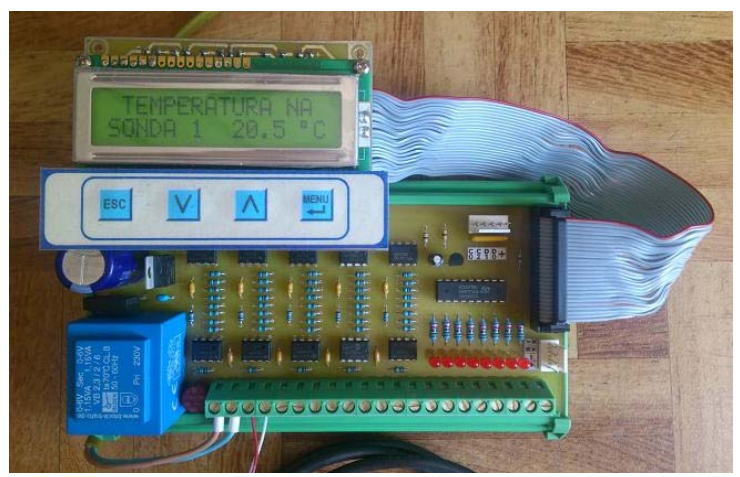

Fig. 7. Solar thermal system control unit.

Fig. 8 presents the controller interface circuit board, based on the following elements : Power supply - $230 \mathrm{~V} / \mathrm{AC}, 50 \mathrm{~Hz}$; 5 analogue input units; (one for each PT 1000 probe) and 8 digital output units (negative logic) to interface the circuit with electronic valves and pumps.

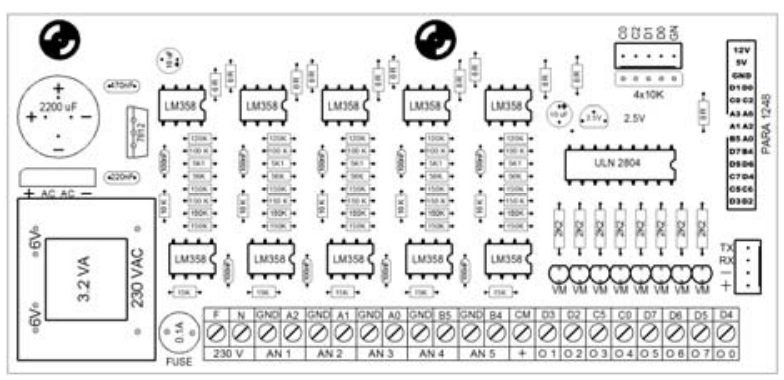

Fig. 8. Controller interface board layout.

Moreover there are integrated in PCB board an outlet for connecting interfaces namely: a socket plug connector RS232 TTL; a connection socket to the programming interface In Circuit Serial Programming (ICSP); and four digital inputs, to be connected to consumption counters (DHW, electricity, etc.)

The implemented controller electronic circuit uses also the PCF8583 clock and a calendar chip, based on a 2048 bit static CMOS RAM organized as 256 words by 8 bits. The chip 
contains also an 8 bit auto-increment address register, an onchip $32.768 \mathrm{kHz}$ oscillator circuit, a frequency divider, a serial two-line bidirectional I2C-bus interface. The first 8 bytes of the RAM are used for the clock, calendar (four years), and counter functions. The next 8 bytes can be programmed as alarm registers or used as free RAM space.

In the controller conditioning circuit design it was assumed that the resistance value of the PT 1000 sensor follows the Callendar-Van Dusen equation

$$
R(T)=R_{0} \cdot\left(1+A \cdot T+B \cdot T^{2}+C \cdot(T-1000) \cdot T^{3}\right)
$$

where $R_{0}$ is the probe element's resistance at $0{ }^{\circ} \mathrm{C}(\Omega), T$ is the probe element's temperature $\left({ }^{\circ} \mathrm{C}\right)$ being the $\mathrm{A}, \mathrm{B}, \mathrm{C}$ constants derived from resistance measurements at multiple temperatures. The standard values obtained from [14] are: $R_{0}=1000 \Omega ; A=3.9083 \times 10^{-3}{ }^{\circ} \mathrm{C}^{-1} ; B=-5.775 \times 10^{-7}{ }^{\circ} \mathrm{C}^{-2}$ and $C=-4.183 \times 10^{-12}{ }^{\circ} \mathrm{C}^{-4}$, for $T<0{ }^{\circ} \mathrm{C}$ and $C=0$ to $T \geq 0{ }^{\circ} \mathrm{C}$.

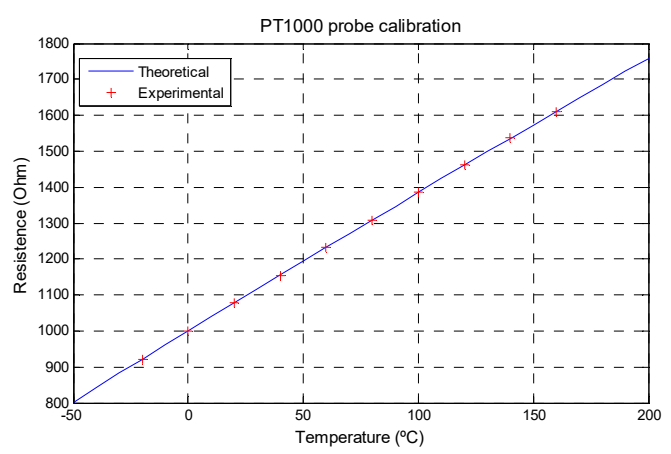

Fig. 9. PT 1000 sensor calibration.

Fig. 9 presents the PT 1000 probe resistance values measured on a temperature in the range from $-20^{\circ} \mathrm{C}$ to $160{ }^{\circ} \mathrm{C}$. The PT 1000 probe resistance value increases linearly as the liquid measured temperature rises. The voltage drop across the probe element is used as input of an amplifier stage being its output value digitized using the microcontroller A/D convertor. In order to operate properly the circuit needs to generate a precise current source. The current drive level selection process takes into account sensor self-heating effects. Fig. 10 presents the implemented signal conditioning circuit, for each probe, based on classical instrumentation circuits with OPAMPs.

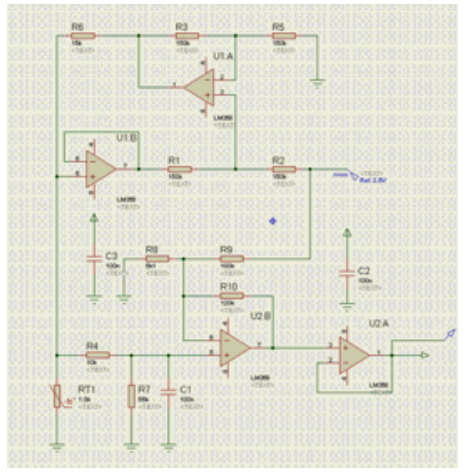

Fig. 10. Signal conditioning circuit for the PT 1000 probes.
Moreover, the Callendar-Van Dusen equation usage in the microcontroller program improves the temperature readings accuracy.

\section{Control Unit Implemented Functions}

The developed controller implements the following set of functions:

- Closed-loop ON/OFF control with hysteresis based on temperatures analysis;

- Anti-legionella function [11].

- Emergency shutdown;

- Maximum and minimum collector temperature;

- Anti-freeze;

As aforementioned the implemented controller system has a RTC PCF8583 which allows the time and date knowledge accurately, even if disconnected from the power source, since it has an external battery to feed it. This capability allows the execution of time scheduled maintenance and shielding operations. The controller main function is the thermal energy flow control between the collector and the hot-water storage tank.

\section{Control system based on temperatures analysis;}

The circulation pump is activated when the temperature difference between collector and storage tank $\Delta \mathrm{T}$ hits the activation $\Delta \mathrm{T}_{\mathrm{ON}}$, and turned off when it reaches the deactivation value $\Delta \mathrm{T}_{\mathrm{OFF}}$. In this case we set the activation $\Delta \mathrm{T}_{\mathrm{ON}}$ equal to $8^{\circ} \mathrm{C}$ and $\Delta \mathrm{T}_{\mathrm{OFF}}$ is $4{ }^{\circ} \mathrm{C}$, these parameters can be modified by means of programming.

\section{Anti-Legionella function}

To eradicate Legionella the solar system should increase the temperature, at least once per week, of the water stored in the tank above $70{ }^{\circ} \mathrm{C}$, during at least one minute, to make sure that all the L. pneumophila bacteria have been eliminated according with [11-13]. During the peak summer the system easily exceeds daily the limit of $70^{\circ} \mathrm{C}$, so the Legionella control is done almost automatically. But when the system detects seven days without temperature rise, the controller automatically waits for the next thermal peak of the day and then uses the backup systems to raise the water temperature. That way, the energy expended is minimized and the efficiency is maximized.

\section{Emergency deactivation}

In order to protect the solar system installation from extreme temperature condition, an emergency shutdown function was planned to prevent the damages that arise from system components overheating, so when the collector reaches the set value $\left(120^{\circ} \mathrm{C}\right)$, the function is activated in order to reduce its value.

Maximum collector temperature function prevents the evaporation of the heat transfer fluid. It is activated when the collector reaches the maximum temperature $\left(120^{\circ} \mathrm{C}\right)$. In this situation the circulation pump is activated to cool the fluid via the heat loss that occurs in the outdoor pipes and promote the 
heat transfer from the fluid to the water stored in the tank, with the main purpose to reduce the fluid temperature.

\section{Minimum temperature collector}

When the temperature on the collectors is lower that temperature pre-set $\left(15^{\circ} \mathrm{C}\right)$, the solar pump turns off, even if the temperature difference between collector and storage tank exceeds the temperature of activation. This function is deactivated only when the collector temperature is $3{ }^{\circ} \mathrm{C}$ higher than the mentioned value.

\section{Anti-freeze}

When the collector temperature falls below the anti-freeze temperature defined $\left(\mathrm{T}_{\mathrm{ACC}}=4{ }^{\circ} \mathrm{C}\right)$, the controller activates the circulating pump during a short period of time. The controller stops the anti-freeze function only when the measured fluid temperature is $3{ }^{\circ} \mathrm{C}$ above the $\mathrm{T}_{\mathrm{ACC}}$ value. Moreover, if the stored water temperature is lower than $12^{\circ} \mathrm{C}$, the controller heats the water using the existent backup system (electrical or gas) until the stored water reach $20^{\circ} \mathrm{C}$. This is a conservative function due to the glycol anti-freeze proprieties.

\section{CONCLUSIONS}

This paper presents the design of two solar water heating system. The first is devoted to a single house family installation with four users the second is a nursing home installation for a large number of users. A new solar system control unit was developed based on the PIC16F887 microcontroller. It includes several new functionalities regarding system and users protection. Additional temperature and liquid level sensors and actuators have been included in the system, to perform the planned functionalities, allowing the system complete control and monitoring.

Human health concerns have been considered knowing that domestic hot water systems with return circuit are often associated to Legionnaires' disease. Thus, using DHW consumption statistics', the solar system increases, at least once per week, the stored water temperature above $70^{\circ} \mathrm{C}$ when it minimizes the energy consumption. Moreover, the implemented functions preclude also critical events that occur when the fluid temperature is extremely low or high, that led respectively to solar fluid freeze and evaporation.

The implemented algorithm employs the solar liquid temperature gradient and the stored water temperature values to achieve the aforementioned targets.

Future work consists on the solar system data integration in the smart grid (home area network), using the available information and communications technologies. This step is crucial to develop new algorithms and perform actions that enable the use of several end-use resources and appliances' on an efficient mode of operation.

\section{ACKNOWLEDGMENT}

This work has been supported by the Portuguese Foundation for Science and Technology (FCT) under project grant UID/MULTI/00308/2013.

\section{REFERENCES}

[1] Philibert, C. (2018, Jan 11), The present and future use of solar thermal energy as a primary source of energy, International Energy Agency, Paris, France, The InterAcademy Council, 2005. Available: http:/www.iea.org/textbase/papers/2005/solarthermal.pdf

[2] Kalogirou, S., Solar energy engineering: processes and system, Elsevier, London, UK, 2014.

[3] Yogi Goswami, D., Kreith, F., Kreider, J. F., "Principles of solar engineering”, Taylor \& Francis, London, UK, 2000.

[4] Morrisson, G. L., Solar Water Heating, Gordon, J. (Ed), Solar energy: The state of the art, James and James, London, UK, 2001, pp.223-289.

[5] Observador (2018, Jan 11), http://observador.pt/2017/11/04/legionellacausou-12-mortos-e-mais-de-400-infetados-em-tres-anos-em-portugal/

[6] Instituto Português da Qualidade (2018, Jan 11), Prevenção e Controlo de Legionella nos Sistemas de Água. Available: http://www1.ipq.pt/ PT/SPQ/ComissoesSectoriais/CS04/Documents/Brochura_Legionella 2014.pdf

[7] RCCTE (2018, Jan 11), Regulamento das Características de Comportamento Térmico dos Edifícios, Decreto-Lei 80/2006 de 4 de Abril (in Portuguese). Available: https://dre.pt/application/file/a/672550

[8] Santos, A. D. (2018, Jan 11), “Avaliação de sistemas solares térmicos de produção de água quente sanitária em edifícios de habitação multifamiliar", MSc. Thesis IST/UTL, Portugal, May 2012. Available: https://fenix.tecnico.ulisboa.pt/downloadFile/395144316395/Tese\%20 Alexandre\%20Santos.pdf

[9] IPMA (2018, Jan 11), Instituto Português do Mar e da Atmosfera. Available: http://www.ipma.pt/pt/

[10] Quaschning, V., "Solar thermal water heating: technology fundamentals", Renewable Energy World, vol. 2/2004, pp. 95-99.

[11] OSHA (2018, Jan 11), Occupational Safety and Health Administration, Technical Manual, Section III, Chapter 7, "Optimum analysis of energy conversion for solar water heating system legionnaires' disease", https://www.osha.gov/dts/osta/otm/otm_iii/otm_iii_7.html.

[12] Mathys (2008). Occurrence of Legionella in hot water systems of single-family residences in suburbs of two German cities with special reference to solar and district heating. Int. J. Hyg. Environ. Health. 2008;211:179-185: doi.org/10.1016/j.ijheh.2007.02.004

[13] Knapp, S. \& Nordell, B. (2017). Energy-efficient Legionella control that mimics nature and an open-source computational model to aid system design. Applied Thermal Engineering, 127, 370-377, Elsevier. Available: https://doi.org/10.1016/j.applthermaleng.2017.08.006

[14] Baker, B. (2018, Jan 11), "Precision temperature sensing with RTD circuits", AN687, Microchip Technology Inc. USA. Available: http://ww1.microchip.com/downloads/en/appnotes/00687c.pdf 